\title{
PERUBAHAN SIFAT FISIK DAN CITA RASA KOPI ARABIKA ASAL BONDOWOSO PADA BERBAGAI TINGKAT PENYANGRAIAN
}

\author{
Hasbi Mubarak Suud ${ }^{*}$, Dyah Ayu Savitri', Safa Rajni Ismaya' \\ 1Prodi IImu Pertanian, Universitas Jember, Indonesia \\ *Co-author: hasbimubarak@unej.ac.id
}

\section{Article Information}

History:

Received: 15-09-2021

Accepted: $26-10-2021$

\section{Keywords:}

Arabica Coffee Flavor

Java Arabica Coffee Physical Properties Roasting

\section{ABSTRACT}

\begin{abstract}
Abstrak: Daerah kaki pegunungan Ijen-Raung Bondowoso merupakan daerah perkebunan penghasil biji kopi arabica yang mempunyai identitas spesialti Java Arabica Coffee. Eksplorasi karakteristik Java Arabica Coffee terus dilakukan untuk memperkuat identitas geografis spesialti dari jenis kopi ini. Penelitian ini merupakan eksplorasi untuk mengkaji efek penyangraian terhadap perubahan karakteristik fisik dan citarasa kopi arabika Bondowoso. Karakteristik fisik yang diamati meliputi rasio berat terhadap volume biji kopi, dimensi kopi, dan indeks warna RGB biji kopi. Pengukuran dimensi kopi meliputi pengukuran tinggi, lebar, dan tebal biji kopi. Citra biji kopi diambil menggunakan kamera mirrorless untuk mengekstrak indeks warna RGB biji kopi pada setiap tingkat sangrai. Pengukuran tingkat citarasa kopi dilakukan dengan uji cup test. Pada penelitian ini diketahui bahwa rasio berat terhadap volume biji kopi dan indeks warna RGB semakin rendah seiring dengan bertambahnya waktu dan suhu sangrai. Selain itu juga terdeteksi adanya perubahan dimensi biji kopi namun perubahan tersebut tidak dominan dapat mendefinisikan tingkat penyangraian. Penyangraian pada suhu maksimal $165^{\circ} \mathrm{C}$ dan waktu total sangrai 9,5 menit menghasilkan gabungan skor aroma, flavor, body, acidity, dan aftertaste terbaik dari kopi arabika Bondowoso.
\end{abstract}

\section{A. LATAR BELAKANG}

Kabupaten Bondowoso merupakan salah satu sentra penghasil kopi di Jawa Timur dengan area penanaman tersebar di kaki Pegunungan Ijen-Raung. Java arabica coffee termasuk dalam produk kopi spesialti dari Bondowoso yang memiliki indikasi geografis. Rantai nilai kopi java arabica mulai dari rangkaian proses penyediaan bahan baku, budidaya, pengolahan green bean hingga bubuk kopi sudah terbentuk melalui lembaga yang sudah tersedia di tingkat petani hingga unit pengolahan hasil (UPH) kopi (Permatasari, Basith and Mulyati, 2018)

Eksplorasi terhadap kopi asal Bondowoso, terutama pada proses pengolahan hilir perlu ditingkatkan untuk memperkuat identitas sebagai kopi spesialti. Salah satu proses pengolahan hilir yang penting adalah proses penyangraian. Proses penyangraian kopi adalah fase krusial untuk mengeluarkan karakteristik rasa dan aroma kopi (Amri et al., 2020). Ada beberapa kriteria yang digunakan untuk mengevaluasi kualitas biji kopi sangrai diantaranya ukuran biji kopi, warna, kualitas rasa, dan persentase banyaknya biji kopi yang rusak
(Rodrigues et al., 2002).Penyangraian kopi merupakan proses perpindahan panas yang kompleks. Perubahahan ukuran, warna, dan cita rasa pada biji kopi selama penyangraian dapat terjadi karena adanya reaksi yang terjadi selama penyangraian seperti reaksi maillard, pirolisis, oksiasi, dan karamelisasi (Edzuan, Majid and Bong, 2015).

Mengenali ciri ciri fisik dan cita rasa kopi pada proses penyangraian penting untuk menjaga konsistensi penyangraian. Tingkat penyangraian dapat dipantau melalui penampakan warna, aroma, dan ukuran biji kopi. Proses penyangraian yang tidak terkendali akan menyebabkan kopi kurang matang atau gosong sehingga mengakibatkan menurunnya kualitas dan cita rasa kopi (Agustini, 2020). Penyangraian sangat dipengaruhi oleh parameter suhu dan waktu dimana setiap jenis kopi memiliki respon yang berbeda terhadap suhu dan waktu penyangraian. Seperti pada kopi robusata asal Semendo, Palembang, terjadi pengurangan kadar air secara gradual hingga 19\% (Agustini, 2020). Kopi robusta asal Rio Minas, Brasil, memiliki kehilangan berat selama penyangraian sebesar 22\% (Jokanović et al., 2012). Sedangkan jenis kopi 
arabika dari Etiopia kehilangan kadar air maksimal sebesar $18.86 \%$ selama proses penyangraian (Anisa, Solomon and Solomon, 2017).

Perbedaan karakterisitik penyangraian pada setiap jenis kopi disebabkan karena perbedaan struktur fisik dan kimia dari tiap jenis kopi. Proses keluarnya kandungan air pada biji kopi selama penyagraian dimulai dari lapisan kulit luar biji kopi. Suhu pada lapisan struktur selulosa dibagian dalam cenderung tetap dingin namun secara gradual menyebabkan adanya penguapan air yang tertahan di bagian dalam kopi dan menyebabkan struktur biji kopi terus mengembang selama proses penyangraian (Rao, 2014)

Penelitian ini bertujuan untuk mengeksplorasi dan mengamati perubahan ciri fisik dan cita rasa kopi Bondowoso selama penyangraian. Dengan mengetahui karakteristik perubahan cita rasa selama penyangraian diharapkan dapat diketahui suhu dan waktu yang terbaik untuk mendapatkan rasa dan aroma terbaik dari kopi. Selain itu juga mengetahui apakah perubahan fisik secara spesifik akan memberikan gambaran bagaimana respon biji kopi Arabika asal Bondowoso terhadap penyangraian.

\section{A. METODE PENELITIAN}

Penelitian ini dilakukan dari bulan Juni - Agustus 2021 di Laboratorium Pengelolaan Panen dan Pasca Panen, Prodi Ilmu Pertanian, Universitas Jember. Sampel yang diamati dalam penelitian ini adalah biji kopi arabika yang dipanen dari dari kaki gunung ijen kabupaten Bondowoso. Biji kopi beras tersebut telah diolah dengan proses natural. Proses penyangraian menggunakan roaster tipe drum dengan setiap kapasitas $1 \mathrm{~kg}$ kopi tiap batch. Roaster dilengkapi dengan exhaust fan dan termokopel beserta data logger. Pencapaian tiap level sangrai dibedakan pada suhu dan waktu penyangraian.

Pengukuran dimensi biji kopi menggunakan 20 sampel biji kopi pada tiap level penyangraian dan pada biji kopi tanpa sangrai dimensinya menggunakan jangka sorong sehingga total terdapat total 120 sampel biji kopi yang diukur dimensinya. Pengukuran meliputi panjang, lebar, dan tebal dari biji kopi seperti ditunjukkan pada Gambar 1.

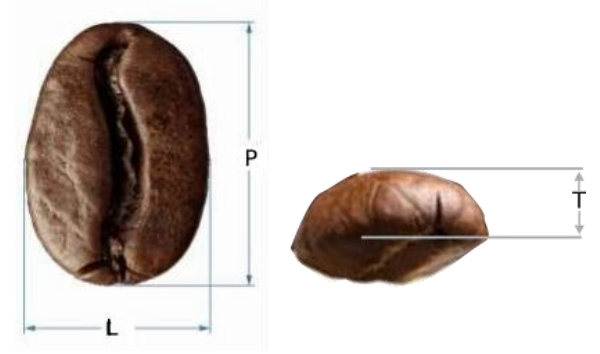

Gambar 1. Pengukuran Dimensi Biji Kopi pada Area Panjang (P), Lebar (L), dan Tebal (T)
Pengukuran rasio berat terhadap volume pada tiap biji kopi baik tanpa sangrai dan pada biji kopi yang sudah disangrai dilakukan dengan cara membandingkan berat biji kopi terhadap dengan volume curah biji kopi. Biji kopi dimasukkan dalam gelas ukur untuk mengetahui volume curah lalu ditimbang menggunakan timbangan digital untuk mendapatkan berat seluruh biji kopi sampel. Setiap pengukuran rasio berat terhadap volume pada setiap tingkat penyangraian dilakukan dengan tiga kali ulangan pengukuran.

Sampel biji kopi pada tiap level penyangraian di foto menggunakan kamera mirrorless pada kotak foto yang kedap cahaya untuk memastikan konsistensi pencahayaan hasil foto. Sususan peralatan yang digunakan untuk mengambil citra/foto kopi dapat dilihat pada Gambar 2. Kamera yang digunakan adalah kamera mirrorless dengan resolusi 16 MP. Sampel kopi difoto tegak lurus dengan jarak $30 \mathrm{~cm}$ dengan terhadap bukaan lensa. Hasil foto dianalisis indeks warna RGB nya menggunakan software imageJ. Model indeks warna RGB adalah model warna berdasarkan konsep penambahan kuat cahaya primer yaitu merah, hijau, dan biru (red, green, blue) (Prabowo and Abdullah, 2018). Setiap jenis biji kopi sangrai akan didefinisikan warnanya dalam bentuk indeks RGB untuk dapat mendefinisikan perbedaan warnanya.

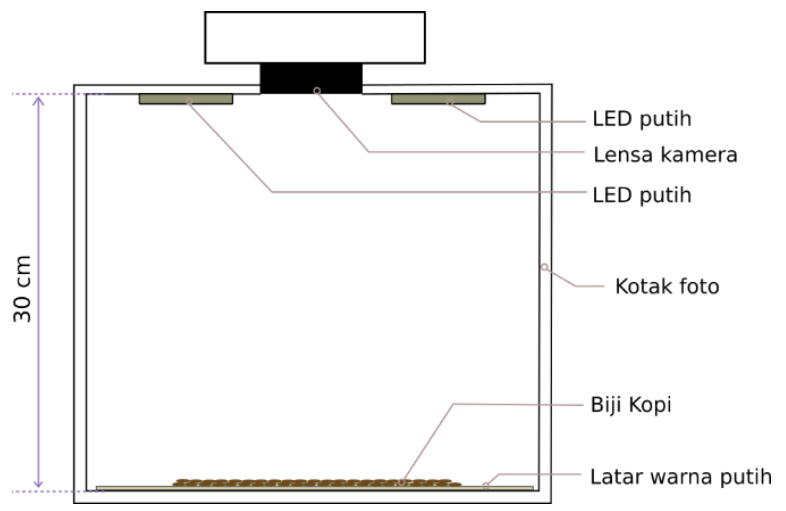

Gambar 2. Susunan Kotak untuk Mengambil Citra Biji Kopi

Analisis cita rasa kopi menggunakan menggunakan uji organoleptik (cup test) yang dilakukan di Pusat Penelitian Kopi dan Kakao (Puslitkoka). Parameter yang diuji meliputi 5 atribut yaitu aroma, flavor, body, acidity, dan aftertaste. Uji organoleptik ini dilakukan oleh minimal 3 orang panelis yang terlatih dan tersertifikasi dan mengacu pada standar Specialty Coffee Association of America (SCAA). Seluruh pengukuran yang dilakukan pada penelitian ini meliputi pengukuran dimensi, rasio berat terhadap volume, indeks warna RGB, dan cup test dilakukan setelah biji kopi yang diroasting mengalami proses cooling sehingga seluruh penguapan pada biji kopi berakhir serta suhunya sudah mencapai suhu kamar. 


\section{B. HASIL DAN PEMBAHASAN}

\section{Proses Penyangraian}

Proses penyangraian biji kopi dilakukan dengan lima tingkat variasi waktu dan suhu sangrai seperti ditunjukkan pada Tabel 1. Waktu total sangrai dan suhu maksimal sangrai selalu ditingkatkan dari tingkat sangrai 1 hingga 5 . Dapat diamati bahwa terjadi perbedaan waktu First crack pada tiap tingkat penyangraian. First crack pada penyangraian tingkat 2 didapatkan sebelum menit ke-8 sedangkan pada penyangraian tingkat 1 belum terjadi first crack. Waktu total penyangraian dan suhu maksimal penyangraian pada tingkat sangrai 3,4 , dan 5 terus ditingkatkan hingga maksimal diatas $200^{\circ} \mathrm{C}$ pada penyangraian tingkat 5 .

Tabel 1.

Waktu dan Suhu Sangrai pada Berbagai Tingkat

\begin{tabular}{|c|c|c|c|c|c|c|c|}
\hline \multirow{3}{*}{$\begin{array}{l}\text { Tingkat } \\
\text { sangrai }\end{array}$} & \multicolumn{6}{|c|}{ Waktu sangrai ke- (menit) } & \multirow{3}{*}{$\begin{array}{c}\text { Waktu } \\
\text { sangrai } \\
\text { total } \\
\text { (menit) }\end{array}$} \\
\hline & 1 & 3 & 5 & 8 & 10 & 14 & \\
\hline & \multicolumn{6}{|c|}{ Suhu sangrai kopi ( $\left.{ }^{\circ} \mathrm{C}\right)$} & \\
\hline Tingkat 1 & 71 & 104 & 131 & 159 & & & 9 \\
\hline Tingkat 2 & 93 & 125 & 142 & $165^{*}$ & & & 9.5 \\
\hline Tingkat 3 & 85 & 112 & 132 & 153 & $165^{*}$ & & 13 \\
\hline Tingkat 4 & 85 & 108 & 131 & 152 & $165^{*}$ & $194^{* *}$ & 14.4 \\
\hline Tingkat 5 & 88 & 114 & 135 & 158 & $172^{*}$ & $204^{* *}$ & 14.6 \\
\hline
\end{tabular}

Waktu terjadinya first crack dan second crack sangat dipengaruhi oleh suhu awal sangrai. Seperti terlihat pada Tabel 1, first crack lebih dahulu terjadi pada penyangraian tingkat 1 dimana suhu awal penyangraian pada penyangraian tingkat 1 lebih tinggi dibandingkan pada penyangraian tingkat 2 . Begitupun pada penyangraian tingkat 1 pada menit ke 8 belum terjadi first crack sedangkan pada penyangraian tingkat 2 sudah terjadi first crack. Hasil penelitian ini serupa dengan hasil studi dari (Münchow et al., 2020) yang menunjukkan bahwa first crack terjadi lebih dahulu pada suhu penyangraian yang lebih tinggi. Pada studi tersebut, first crack terjadi pada menit ke 9 untuk penyangraian pada suhu $160^{\circ} \mathrm{C}$. Sedangkan pada suhu penyangraian $200^{\circ} \mathrm{C}$, first crack terjadi pada menit ke 7 .

Pengaruh suhu awal sangrai terhadap first crack dan second crack disebabkan sebagian besar proses pada penyangraian kopi merupakan proses endotermik dimana biji kopi menyerap energi panas yang disalurkan dari bagian terluar biji kopi menuju bagian inti biji kopi. Kecepatan penyerapan energi panas biji kopi tersebut tergantung pada suhu awal proses penyangraian. Adanya kenaikan suhu memicu timbulnya tekanan pada bagian dalam biji kopi yang diakibatkan uap air yang terperangkap dalam struktur kopi. Tekanan tersebut menyebabkan runtuhnya struktur selulosa kopi sehingga menyebabkan adanya peristiwa first crack dan diikuti oleh proses second crack (Rao, 2014).

\section{Rasio Berat Terhadap Volume Biji Kopi}

Rasio berat terhadap volume lebih tinggi pada biji kopi tanpa sangrai daripada pada biji kopi dengan perlakuan penyangraian seperti ditunjukkan pada grafik Gambar 3. Pada penelitian ini ditunjukkan bahwa penyangraian sangat berpengaruh terhadap perubahan rasio berat terhadap volume biji kopi. Rasio berat volume biji kopi semakin rendah pada tingkat sangrai yang lebih tinggi. Kadar air biji kopi beras sebelum disangrai sebesar $12 \%$. Kopi yang disangrai pada penelitian ini menunjukkan kehilangan berat yang sangat besar. Pada biji kopi yang disangrai pada tingkat 1 mengalami penurunan rasio berat terhadap volume hingga 39\% bila dibandingkan dengan biji kopi yang tanpa disangrai. Bahkan pada biji kopi dengan penyangraian tingkat 5 mengalami penurunan rasio berat terhadap volume hingga $58 \%$ bila dibandingkan berat kopi sebelum disangrai.
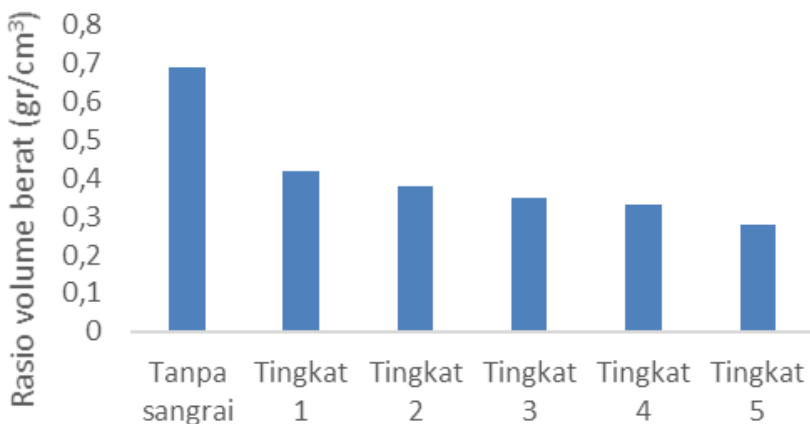

Tingkat sangrai

Gambar 3. Grafik Rasio Berat Terhadap Volume (gr/ $\left.\mathrm{cm}^{3}\right)$ Biji Kopi pada Tiap Tingkat Sangrai

Pittia, Dalla Rosa and Lerici (2001) menyatakan bahwa berkurangnya densitas biji kopi pada suhu dan waktu yang lebih tinggi tersebut mayoritas dipengaruhi oleh berkurangnya kadar air biji kopi. Ada kecenderungan bahwa kehilangan kadar air memiliki peranan besar dalam perubahan sifat fisik kopi. Air memiliki peranan sebagai plasticizer yang mengurangi sifat kekakuan (stiffness) bahan. Kehilangan kadar air pada biji kopi memicu meningkatnya sifat kekakuan biji kopi. Laju kehilangan kadar air biji kopi ini tidak saja mempengaruhi rasio berat terhadap volume biji kopi, tetapi juga mempengaruhi waktu cracking pada saat proses penyangraian.

\section{Dimensi biji kopi}

Perubahan dimensi panjang, lebar, dan tebal ratarata dapat menunjukkan indikasi perubahan volume biji kopi yang disebabkan proses penyangraian. Pada penelitian ini diketahui biji kopi yang telah disangrai memiliki dimensi yang lebih besar daripada biji kopi tanpa sangrai seperti ditunjukan pada grafik di 
Gambar 4. Hal ini menunjukkan bahwa dimensi biji kopi mengembang selama proses sangrai.

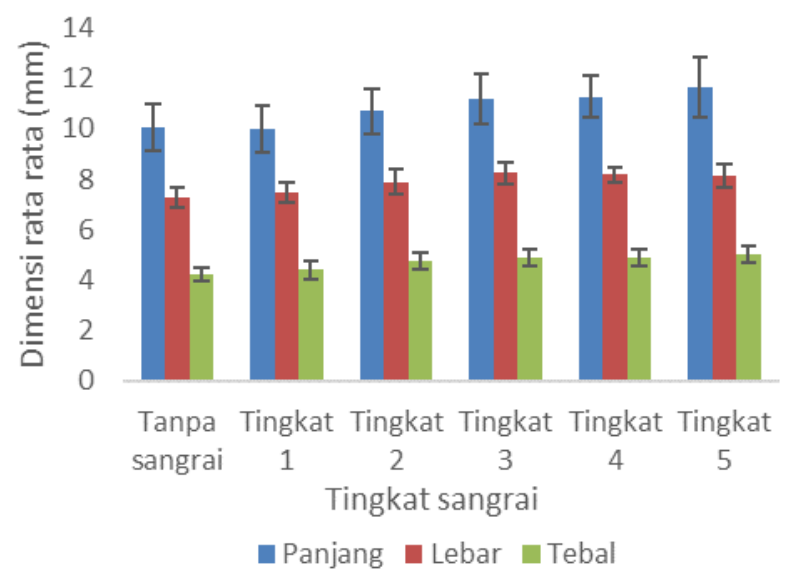

Gambar 4. Grafik Rerata Dimensi Biji Kopi yang Meliputi Panjang (P), Lebar (L), dan Tebal (T) pada Tiap Tingkat Sangrai

Pertambahan panjang dan tebal rata rata biji kopi terbesar ditemukan pada tingkat sangrai 5 yaitu $15.4 \%$ lebih panjang dan $18.8 \%$ lebih tebal dibandingkan pada biji kopi sebelum disangrai. Pertambahan dimensi lebar rata-rata terbesar ditemui pada tingkat sangrai 3 yaitu $13.3 \%$ lebih lebar dibandingkan biji kopi tanpa sangrai. Namun pada penelitian ini perubahan dimensi biji kopi tidak bisa dijadikan dasar dalam menentukan tingkat sangrai kopi karena variasi ukuran sampel biji kopi yang diroasting cukup besar. Selain itu perubahan dimensi antara biji kopi yang disangrai dan belum disangrai yang terukur pun sangat kecil yaitu antara $0.07 \mathrm{~mm}$ hingga $1.56 \mathrm{~mm}$. Hasil studi dari Pimenta et al. (2009) menunjukkan adanya proses pengembangan biji kopi tipe flat pada profil sangrai yang berbeda. Pertambahan panjang, lebar, dan tebal maksimal yang diukur pada studi tersebut berturut turut adalah sebesar 16.9\%, 22.9\%, dan $25.7 \%$ yang didapatkan pada waktu sangrai 13 menit dan suhu akhir sangrai $212^{\circ} \mathrm{C}$. Pertambahan dimensi yang didapatkan oleh Pimenta et al. (2009) lebih besar daripada yang didapatkan pada hasil pengukuran penelitian ini. Namun data-data tersebut menunjukkan bahwa terdapat pertambahan dimensi biji kopi yang menyebabkan pengembangan volume kopi selama proses penyangraian.

\section{Indeks Warna RGB Biji Kopi}

Pengambilan citra dari tiap biji kopi tersebut dilakukan menggunakan kamera mirrorless digital dalam kotak tertutup untuk meminimalkan noise cahaya dari luar kotak. Lalu selanjutnya dilakukan esktraksi nilai indeks warna RGB (red, green, blue) pada hasil setiap citra biji kopi tersebut. Setiap citra biji kopi memiliki indeks warna RGB tertentu. Warna dari suatu objek dapat dijabarkan pada perbedaan prosentase indeks warna RGB. Pada penelitian ini perubahan warna biji kopi menjadi semakin gelap seiring dengan meningkatnya tingkat sangrai kopi seperti ditunjukkan pada Gambar 5 .
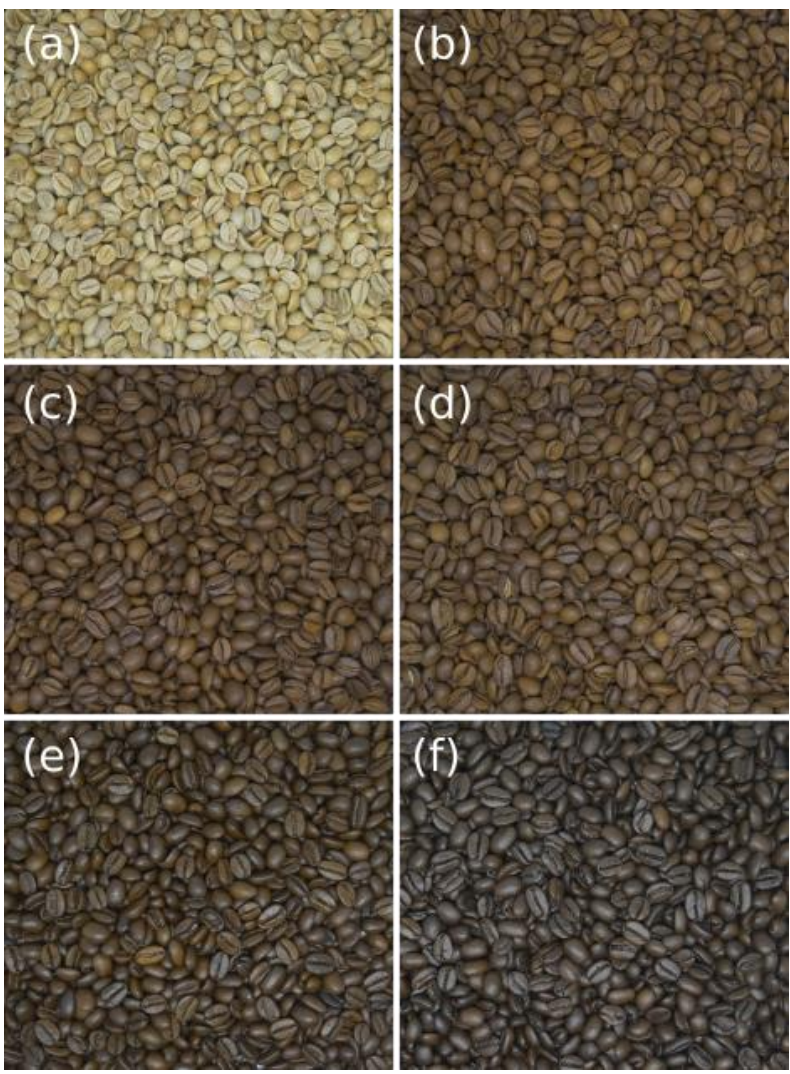

Gambar 5. Foto Biji Kopi (a) Tanpa Sangrai, (b) Sangrai Tingkat 1, (c) Sangrai Tingkat 2, (d) Sangrai Tingkat 3, (e) Sangrai Tingkat 4, dan (f) Sangrai Tingkat 5

Pada hasil citra biji kopi mulai dari pada sangrai tingkat 3 hingga tingkat 5 mulai muncul pemantulan cahaya dari lampu led putih yang ada di kotak foto. Hal ini merupakan indikasi dari munculnya minyak pada kulit biji kopi sehingga terjadi polarisasi cahaya dari permukaan biji kopi karena minyak merupakan bahan optik aktif (Nuraniza, Lapanporo and Arman, 2013). Biji kopi memiliki kandungan lipid atau minyak kopi hingga $18 \%$. Perubahan struktur biji kopi selama penyangraian pada titik tertentu dapat menyebabkan rusaknya struktur yang mengikat minyak yang terkandung dalam kopi dan mengeluarkan minyak tersebut ke permukaan biji kopi (Folmer, 2017).

Adanya pemanasan di fase awal penyangraian menyebabkan air dan kandungan volatil menguap secara berlahan sehingga menyebabkan kopi menjadi menguning. Semakin lama proses pemanasan berlangsung maka mulai terjadi pirolisis yang menyebabkan reaksi kimia dan fisika lebih lanjut terjadi. Pada tahapan ini penguapan kadar air semakin masif dan biji kopi warnanya menjadi lebih gelap karena ada kadar gula yang terkaramelisasi. Jika semakin lama disangrai maka kopi akan tebakar dan cenderung gosong menghasilkan warna lebih hitam (Rodrigues et al., 2002). 
Jurnal AGROTEK Vol. 8, No. 2, 2021/Perubahan Sifat Fisik dan Cita Rasa Kopi Arabika Asal Bondowoso pada Berbagai Tingkat Penyangraian /Hasbi Mubarak Suud, Dyah Ayu Savitri, Safa Rajni Ismaya

Tabel 2.

Indeks Warna RGB Biji Kopi pada Tiap Tingkat Sangrai

\begin{tabular}{lcccccc}
\hline \multirow{2}{*}{$\begin{array}{c}\text { Jenis } \\
\text { penyangraian }\end{array}$} & \multicolumn{2}{c}{$\operatorname{Red}(\mathrm{R})$} & \multicolumn{2}{c}{ Green $(\mathrm{G})$} & \multicolumn{2}{c}{ Blue (B) } \\
\cline { 2 - 7 } & Rerata & STD & Rerata & STD & Rerata & STD \\
\hline Tanpa Sangrai & 154 & 7.7 & 143 & 7.9 & 105 & 7.6 \\
Tingkat 1 & 92 & 5.8 & 74 & 4.0 & 105 & 2.4 \\
Tingkat 2 & 81 & 3.3 & 66 & 2.4 & 51 & 2.0 \\
Tingkat 3 & 87 & 4.2 & 72 & 2.9 & 55 & 1.6 \\
Tingkat 4 & 71 & 3.1 & 62 & 2.5 & 50 & 3.2 \\
Tingkat 5 & 68 & 3.3 & 63 & 2.8 & 58 & 2.6 \\
\hline
\end{tabular}

Dalam penelitian ini nilai indeks warna RGB dipisahkan setiap komponennya dan dijadikan parameter untuk melakukan klasifikasi. Indeks warna RGB biji kopi pada tiap tingkat sangrai dijabarkan dalam nilai rerata dan standar deviasi (STD) pada tiap komponen red, green, dan blue seperti terlihat pada Tabel 2. Nilai rerata adalah nilai intensitas rata-rata tiap indeks warna RGB. Sedangkan nilai STD menunjukkan penyimpangan maksimum dari nilai intensitas rata-rata pada tiap komponen red, green, dan blue. Nilai STD pada penelitian ini cukup rendah yaitu nilainya berada dibawah 10. Berdasarkan data tersebut diketahui bahwa indeks warna RGB semakin rendah seiring bertambahnya tingkat sangrai kopi. Semakin rendah indeks warna menunjukkan objek semakin gelap dan sebaliknya semakin tinggi indeks warna maka menunjukkan objek semakin terang (Bustomi and Dzulfikar, 2014).

\section{Cita Rasa Kopi}

Aroma menggambarkan kenyamanan dari bau aromatik baik ketika biji kopi belum diseduh atau setelah diseduh. Lalu flavor menggambarkan intensitas, kualitas, dan kompleksitas rasa yang dapat dinikmati oleh indra mulut dan hidung. Acidity mendeskripsikan bagaimana munculnya karakteristik yang seimbang dari fruity, manis, asam, dan rasa khas pada saat tegukan pertama ketika kopi dinikmati. Body menunjukkan seberapa liquid atau kentalnya kopi yang dirasakan oleh lidah dan roangga atas mulut. Kehadiran body kopi biasanya disebabkan karena kandungan koloid dan sukrosa yang tebal pada kopi. Aftertaste adalah kesan yang dirasakan oleh bagian langit langit mulut terhadap rasa dan aroma kopi setelah kopi ditelan (SCAA, 2015).

Proses penyangraian merupakan proses yang sangat mempengaruhi cita rasa kopi. Proses pemanasan biji kopi akan selalu merubah cita rasa kopi secara terus menerus. Tabel 3 menunjukkan perubahan cita rasa pada 5 karakteristik tingkat sangrai. Tingkat sangrai kopi yang lebih dark cenderung akan menghilangkan acidity kopi seperti pada biji kopi yang disangrai pada tingkat 5 pada penelitian ini. Selain itu pada tingkat sangrai yang lebih dark juga menyebabkan senyawa volatil yang ada di biji kopi menguap sehingga menyebabkan aroma kopi menjadi menghilang seperti yang juga terlihat pada penyangraian tingkat 5 . Proses sangrai dapat memunculkan dan membangkitkan cita rasa kopi, namun jika tidak dilakukan dengan suhu dan waktu yang tepat akan menyebabkan kopi menjadi lebih gosong dan gelap sehingga menghilangkan cita rasa potensialnya.

Tabel 3.

Nilai Uji Organoleptik Citarasa Kopi pada Tiap Tingkat Sangrai

\begin{tabular}{cccccc}
\hline \multirow{2}{*}{$\begin{array}{c}\text { Atribut } \\
\text { Organoleptik }\end{array}$} & $\mathbf{5}$ & \multicolumn{5}{c}{ Tingkat sangrai } \\
\cline { 2 - 6 } & \multicolumn{5}{c}{ Nilai } \\
\cline { 2 - 6 } Aroma & 7 & 7.63 & 7.25 & 7.25 & 6.63 \\
Flavor & 6.88 & 7.88 & 7.63 & 7.25 & 6.75 \\
Body & 6.63 & 7.88 & 7.75 & 7.63 & 7.38 \\
Acidity & 7.25 & 7.63 & 7.75 & 6.25 & 3.25 \\
Aftertaste & 6.88 & 7.75 & 7.75 & 7.38 & 6.75 \\
\hline Skor total & 34.6 & 38.8 & 38.1 & 35.8 & 30.8 \\
\hline
\end{tabular}

Pada penelitian cita rasa kopi ditentukan hanya pada 5 atribut penilaian uji organoleptik saja yaitu aroma, flavor, body, acidity, dan aftertaste. Berdasarkan data dari Tabel 3, penyangraian pada tingkat 2 menghasilkan cita rasa kopi terbaik karena memiliki nilai total tertinggi untuk atribut aroma, flavor, body, acidity, dan aftertaste. Nilai atribut total cita rasa kopi yang terendah ditemukan pada kopi dengan tingkat sangrai 5 . Pada tingkat sangrai 1 rasa dan aroma kopi belum keluar seluruhnya, namun sebaliknya pada kopi dengan tingkat sangrai 5, rasa dan aroma kopi telah banyak yang hilang dan digantikan oleh rasa gosong yang membuat tidak nyaman bagi panelis.

\section{SIMPULAN DAN SARAN}

Proses penyangraian memberikan perubahan fisik pada biji kopi yang meliputi perubahan dimensi, rasio berat terhadap volume, dan perubahan warna biji kopi. Pertambahan maksimal dimensi panjang, lebar, dan tebal biji kopi berturut-turut sebesar 15.4\%, 13.3\%, dan 18.8\% dibandingkan pada biji kopi sebelum disangrai. Rasio berat terhadap volume menjadi semakin rendah seiring bertambahnya suhu dan waktu penyangraian. Penurunan rasio berat terhadap volume paling tinggi ada pada tingkat sangrai 5 yaitu sebesar $58 \%$. Nilai indeks warna RGB juga semakin rendah dimana warna biji kopi semakin gelap seiring dengan meningkatnya tingkat sangrai. Cita rasa terbaik berdasarkan atribut organoleptik aroma, flavor, body, acidity dan aftertaste didapatkan pada biji kopi denga tingkat sangrai 2 yaitu penyangraian dengan waktu sangrai total 9.5 menit dan suhu akhir penyangraian $165^{\circ} \mathrm{C}$. Penelitian ini dapat dilanjutkan dengan membahas lebih detil bagaimana perubahan sifat kimia selama penyangraian kajian mengenai Java Arabica Coffee 
sebagai kopi spesialti asal Bondowoso dapat dieksplorasi lebih dalam lagi.

\section{UCAPAN TERIMA KASIH}

Penulis mengucapkan terima kasih kepada LP2M Universtas Jember yang telah mensupport penelitian ini melalui kelompok riset teknologi pasca panen komoditas perkebunan yang berada di bawah binaan Prodi Ilmu Pertanian Universitas Jember.

\section{DAFTAR RUJUKAN}

Agustini, S. (2020) 'perubahan sifat fisika kimia kopi robusta asal semendo pada berbagai level penyangraian', Jurnal Dinamika Penelitian Industri, 31(1), p. 79 . doi: 10.28959/JDPI.V31I1.6144.

Amri, A. F. et al. (2020) 'identifikasi profil kualitas kopi sebagai acuan pengembangan produk spesialti di kawasan menoreh, kulon progo, yogyakarta', Jurnal Industri Hasil Perkebunan, 15(1), pp. 17$28 . \quad$ Available at: http://litbang.kemenperin.go.id/bbihp/article/vie w/5776 (Accessed: 30 August 2021).

Anisa, A., Solomon, W. K. and Solomon, A. (2017) 'Optimization of roasting time and temperature for brewed hararghe coffee (Coffea Arabica L.) using central composite design', International Food Research Journal 2, 24(6), pp. 2285-2294. Available at: https://www.researchgate.net/publication/343648 384_Optimization_of_roasting_time_and_tempe rature_for_brewed_hararghe_coffee_Coffea_Arab ica_L_using_central_composite_design (Accessed: 31 August 2021).

Bustomi, M. A. and Dzulfikar, A. Z. (2014) 'Analisis Distribusi Intensitas RGB Citra Digital untuk Klasifikasi Kualitas Biji Jagung menggunakan Jaringan Syaraf Tiruan', Jurnal Fisika dan Aplikasinya, 10(3), pp. 127-132. doi: 10.12962/J24604682.V10I3.791.

Edzuan, A. M. F., Majid, N. A. A. and Bong, H. L. (2015) 'Physical and Chemical Property Changes of Coffee Beans during Roasting', American Journal of Chemistry, 5(3A), pp. 56-60. doi: 10.5923/C.CHEMISTRY.201501.09.

Folmer, B. (2017) The Craft and Science of Coffee. 1st edn. London: Academic Press.

Jokanović, M. R. et al. (2012) 'Changes of physical properties of coffee beans during roasting, Acta Periodica Technologica, 43, pp. 21-31. doi: 10.2298/APT1243021J.

Münchow, M. et al. (2020) 'Roasting Conditions and Coffee Flavor: A Multi-Study Empirical Investigation', Beverages 2020, Vol. 6, Page 29, 6(2), p. 29. doi: 10.3390/BEVERAGES6020029.

Nuraniza, N., Lapanporo, B. P. and Arman, Y. (2013) 'Uji Kualitas Minyak Goreng Berdasarkan Perubahan Sudut Polarisasi Cahaya Menggunakan Alat Semiautomatic Polarymeter', PRISMA FISIKA,
1(2), pp. 87-91. doi: 10.26418/PF.V1I2.3014.

Permatasari, P. C. (Prisca), Basith, A. (Abdul) and Mulyati, H. (Heti) (2018) 'Model Bisnis Inklusif Rantai Nilai Kopi Arabika di Bondowoso Jawa Timur', Jurnal Manajemen Teknologi, 17(2), pp. 111-125. doi: 10.12695/JMT.2018.17.2.3.

Pimenta, t. V. Et al. (2009) 'roasting processing of dry coffee cherry: influence of grain shape and temperature on physical, chemical and sensorial grain properties', Boletim do Centro de Pesquisa de Processamento de Alimentos, 27(1), pp. 97-106. doi: 10.5380/CEP.V27I1.14956.

Pittia, P., Dalla Rosa, M. and Lerici, C. R. (2001) 'Textural Changes of Coffee Beans as Affected by Roasting Conditions', LWT - Food Science and Technology, 34(3), pp. 168-175. doi: 10.1006/FSTL.2000.0749.

Prabowo, D. A. and Abdullah, D. (2018) 'Deteksi dan Perhitungan Objek Berdasarkan Warna Menggunakan Color Object Tracking', Pseudocode, 5(2), pp. 85-91. doi: 10.33369/PSEUDOCODE.5.2.85-91.

Rao, S. (2014) The Coffee Roaster's Companion by Scott Rao. first edition. Available at: https://www.scottrao.com/ (Accessed: 9 June 2021).

Rodrigues, M. A. A. et al. (2002) 'Evolution of physical properties of coffee during roastin', pp. 1-. doi: 10.13031/2013.9759.

SCAA (2015) SCAA Protocols | Cupping Specialty Coffee. Available at: https://www.scaa.org/PDF/resources/cuppingprotocols.pdf (Accessed: 15 May 2021). 